\title{
Revealing unique inscriptions of a Nazi collaborator in Doodencel 601 of the Oranjehotel
}

\author{
Joost Wempe ${ }^{1 \dagger}$, Rick van den Brink ${ }^{1 \dagger}$, Esmée Mooldijk $^{1 \dagger}$, Nienke Feirabend $^{1 \dagger}{ }^{1 \dagger}$ Ruben Wiersma ${ }^{2}$, Jilt Sietsma ${ }^{1}$ \\ and Joris Dik ${ }^{1 *}$ (D)
}

\begin{abstract}
During the Second World War the German occupants of the Netherlands made ample use of the Scheveningen prison near The Hague, popularly nicknamed the Oranjehotel. One former death cell in this infamous prison (Doodencel 601) has been preserved in its original condition, showing wartime inscriptions on the cell walls. Interestingly, a small section of the wall has been given an additional plaster layer, presumably covering inscriptions. Here, we report on the visualization of this enigmatic text, which so far had escaped the reach of historians. Our visualization methodology was threefold. First, we determined the cell-wall stratigraphy and its composition based on a sample crosssection. Second, we prepared a physical model wall, mimicking the layering of the original cell wall. Third, we tested a combination of raking light photography and infrared thermography on the model wall. Applying this methodology on the original wall revealed the inscriptions, including the author's name Daniël de Bloca van Scheltinga, a prominent Nazi collaborator, as well as a calendar and an important date of his post-war trial in the fall of 1945. Our visualizations flawlessly dovetail with archival findings. Together, they offer an intimate view of an early post-war inmate of the Scheveningen prison, whose message was covered up once the cell was transformed into a war monument in 1946.
\end{abstract}

\section{Introduction}

During the German occupation of the Netherlands between May 1940 and May 1945, more than 25,000 people were held captive in the Deutsches Untersuchungsund Strafgefängnis in the Scheveningen prison, near The Hague [1]. Nicknamed the Oranjehotel by the Dutch population, the prison played a prominent role in the Nazi judicial system in the Netherlands. Many Dutchmen were taken here immediately after their arrest on suspicion of anti-German activities, facing interrogation and trial, including brutal torture. Sentences included the death penalty, resulting in 215 resistance fighters being led from the Oranjehotel to their execution in the nearby dunes, the infamous Waalsdorpervlakte. Those sentenced

\footnotetext{
*Correspondence: J.Dik@tudelft.nl

${ }^{\dagger}$ Joost Wempe, Rick van den Brink, Esmée Mooldijk and Nienke Feirabend are first authors

1 Dept. Materials Science and Engineering, Delft University of Technology, Mekelweg 2, 2628 CD Delft, The Netherlands

Full list of author information is available at the end of the article
}

to death spent their last days in the middle cell row, the $D$-gang, part of which was the death row section of the Oranjehotel [2].

After the liberation in May 1945, the Dutch authorities maintained the prison function, initially to imprison collaborators that were on trial at the Bijzonder Gerechtshof (Special Court of Justice) (1945-1948), accused of high treason, treason or war crimes. Later the prison remained operative until 2009. The first post-war warden, E.P. Weber, recognized the unique historical and emotional significance of the Oranjehotel. A committee that he founded and chaired decided to establish one death cell as a war monument by excluding it from further prison use in 1946. Thus the selected cell, Doodencel 601 (Fig. 1), effectively became a time capsule, preserving its wartime significance. The cell contains its original wooden furniture and also the walls and floor are in the original state. Very importantly, the walls bear inscriptions carved by resistance fighters and other wartime prisoners: texts, names, calendars, drawings expressing hope and despair,
Springer Open

(c) The Author(s) 2020. This article is licensed under a Creative Commons Attribution 4.0 International License, which permits use, sharing, adaptation, distribution and reproduction in any medium or format, as long as you give appropriate credit to the original author(s) and the source, provide a link to the Creative Commons licence, and indicate if changes were made. The images or other third party material in this article are included in the article's Creative Commons licence, unless indicated otherwise in a credit line to the material. If material is not included in the article's Creative Commons licence and your intended use is not permitted by statutory regulation or exceeds the permitted use, you will need to obtain permission directly from the copyright holder. To view a copy of this licence, visit http://creativeco mmons.org/licenses/by/4.0/. The Creative Commons Public Domain Dedication waiver (http://creativecommons.org/publicdomain/ zero/1.0/) applies to the data made available in this article, unless otherwise stated in a credit line to the data. 


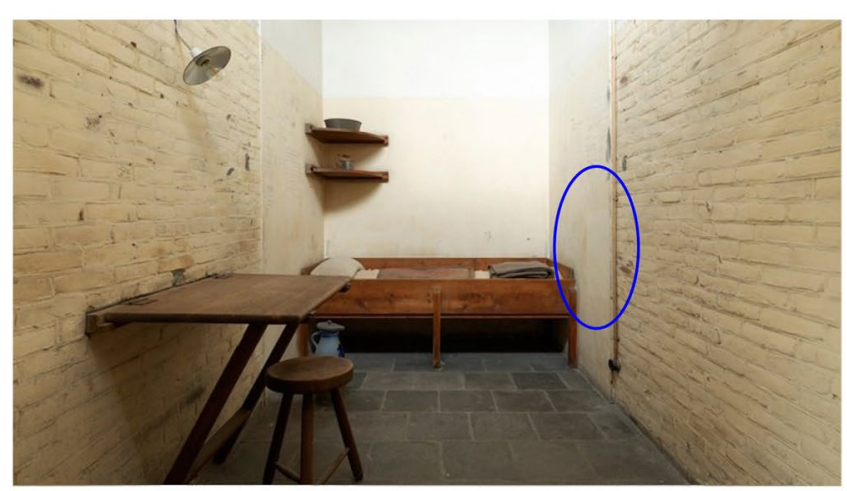

$\mathbf{a}$
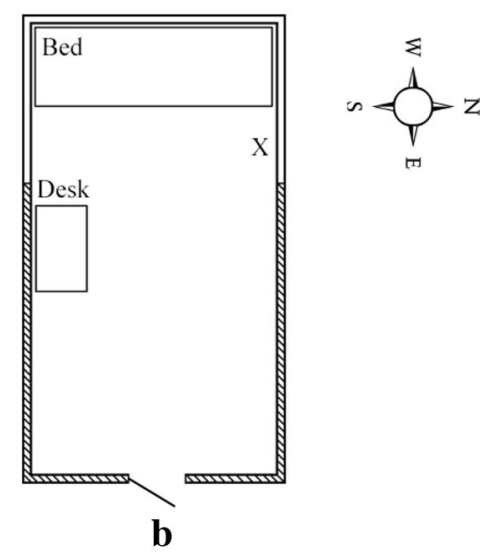

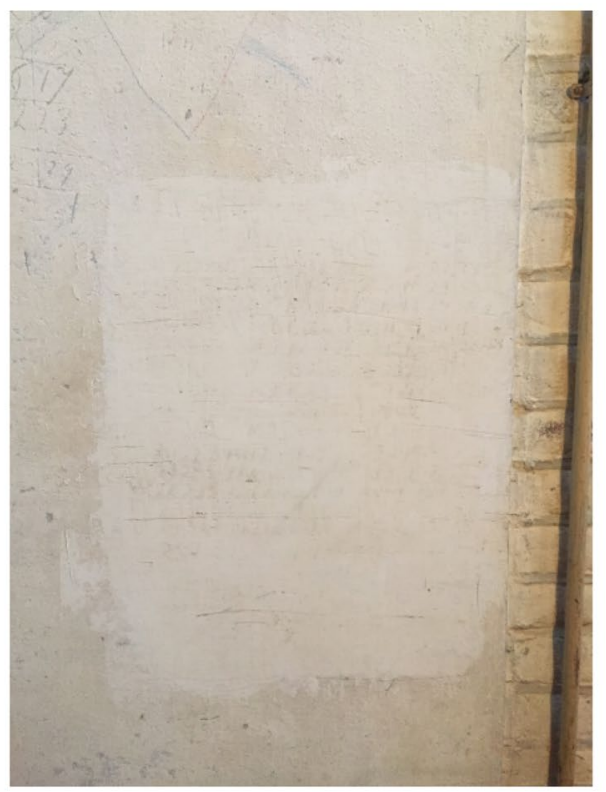

c

Fig. 1 a Death cell 601 in the present state, preserving the wartime characteristics. The dimensions of the cell are approximately $3.7 \mathrm{~m} \times 1.9 \mathrm{~m}$. The post-war plastered section of the northern wall is indicated by the ellipse. $\mathbf{b}$ Floor plan of cell 601 . The walls are built of brick, on the eastern part of the cell the bricks are painted in yellow (dashed) and in the western part of the cell a layer of mortar has been applied on the bricks. The X marks the location of the post-war plaster covering inscriptions in the wall. b Close-up of the $45 \mathrm{~cm} \times 60 \mathrm{~cm}$ post-war plastered section of the northern wall

anti-German feelings, religious faith, loyalty to the country and the royal house (Oranje), affection for loved ones and also black humour [2]. Together, the inscriptions symbolise the horrors of the Second World War, but also testify of individual emotions of Nazi victims facing their death.

All cells formerly used by the Nazis remained in use until 2009 when the prison was given a Dutch national heritage status. In 2019 the former Nazi prison block was opened as the Nationaal Monument Oranjehotel; the prison, including Doodencel 601, is now open to the public.
Whereas the walls of cell 601 are well preserved and in good condition, clearly showing the many wartime inscriptions, a rectangular section of the wall near the bed, measuring approximately $45 \mathrm{~cm} \times 60 \mathrm{~cm}$, has been plastered in a rather rough manner (Fig. 1a, c). The plastering of this part of the wall in 1946 is documented in an architectural note [3]. In the post-war period from May 1945 to August 1946 the cell was used, like all other cells, to detain suspects of collaboration. In this period the Scheveningen prison population included some leading members of the Dutch National-Socialist Movement (Nationaal-Socialistische Beweging, NSB) [4]. Like the 
resistance fighters during the Nazi occupation, post-war prisoners have left inscriptions in cell walls, including walls of cell 601 [3]. Before the inauguration of the cell as a monument in October 1946 it was decided to cover the post-war inscriptions with plaster [3]. In cell 601 no postwar inscriptions are recognised in the cell walls as they can be seen now. All other cells have been redecorated in the decades after the war, leaving no trace of inscriptions. Moreover, nothing has been documented on the inscriptions of post-war prisoners. This leaves the plastered part of the wall of cell 601 as the only possibility to acquire information on post-war inscriptions of suspects of collaboration with the Nazi's. It is therefore of historical interest to reveal the contents and identify the author and date. Traces of letters and numbers are visible in the plaster's surface topography, indicating that inscriptions have been covered. Visual inspection indicates that the surface traces on the plaster coincide with the actual underlying inscriptions. This implies that no highly sophisticated techniques, aiming for a high resolution or depth analysis, were necessary for this study. The present historic study focuses on the analysis of the surface and near-surface information. A non-destructive imaging campaign was designed, aiming to visualize this enigmatic text and shed light on the post-war history of Doodencel 601. The present paper reports on a historic text that was revealed by application of non-destructive raking light photography and infrared thermography. The resulting information of the inscriptions is presented and discussed, in its historical context.

\section{Methods and techniques}

It should be noted that the historic character and spatial limitations of Death Cell 601 excluded the execution of the research in fully optimised conditions. Because of the delicate state of the cell and its heritage status, the conservator-in-charge strictly limited the access of people and equipment as well as research time for data acquisition. Therefore, the present study does not aim at pushing the analytical limits of non-destructive imaging, but rather on revealing the historic inscriptions.

Over the past two decades, thermography has found many applications in the study of layered objects in cultural heritage [5-7]. More recent papers have shown how advanced forms of thermography have been very successful in optimizing the revelation of hidden features on (re)plastered wall paintings. Davin et al. have demonstrated the effectiveness of cooling-down infrared thermography [8]. Their method showed a significant step forward in depth resolution as well as the potential to study the nature of pigments in hidden layers. Daffara et al. have combined thermography and thermal quasi-reflectography in effectively mapping both surface materials and subsurface detachments in mural paintings [9]. A further integration of thermography in a multi-modal, surface and subsurface Non-Destructive Testing (NDT) campaign was shown by Sfarra et al. in the characterization of a fresco in the Church of Santa Maria di Collemaggio, heavily damaged during the 2009 L'Aquila earthquake [10]. In addition to thermography, TeraHertz spectroscopy has become available, both for the subsurface study of easel paintings [11, 12], as well as plastered structures such as mural paintings [13]. While some of the approaches described above would have been promising to apply to the current case study, the limitations described above -as well as the unavailability of more advanced techniques- prevented us from doing so.

\section{Raking light photography}

Raking light photography is a technique in which a specimen is illuminated at an oblique angle in relation to its surface. By doing this, the light will accentuate the irregularities located at the surface, visualizing the topography of a surface in a qualitative manner. A more quantitative approach is Reflectance Transformation Imaging (RTI). This usually involves the lighting of a surface from multiple angles with a handheld lighting source, after having placed reflective spheres near the surface to record the direction of the light. This results in an interactive display of the surface with variable lighting conditions for later study. First proposed by Malzbender two decades ago [14], the method is now routinely used in the characterization of cultural heritage such as wall graffiti [15]. In our case, some inscribed characters were already visible to the naked eye and we anticipated that a small accentuation of the topography would result in legible images. That is why we chose to use raking light photography instead.

In the present study, the wall section of interest in cell 601 has been divided into 6 columns and 4 rows ( 24 sections). Pictures were made of every section using a Canon 500D camera with the light directed from the top, bottom, left and right side, almost perpendicular to the wall. The camera was placed on a monopod positioning it at the same height as each studied section. Due to the strict constraints of the historic cell, including the uneven floor, accurate quantification of the angles and distances was not possible. By merging the four pictures from top, bottom, left and right using Adobe Photoshop CC 2019๑, a complete mapping of the surface is made. In an earlier preliminary study a part of the plastered wall section was tested to probe the feasibility of a more extensive study [16]. 


\section{Thermography}

Thermography is a technique in which a specimen is heated, for example by visible light, and the temperature distribution at the surface of the specimen is recorded in a thermal image, using specialised scanning cameras. If a surface with a uniform colour and texture is thus viewed with an infrared camera it will appear uniform in case the wall material is free of defects. Cracks, delamination and other defects within the wall material decrease its thermal conductivity. Consequently, at these locations the surface will heat up faster under irradiation, since the dissipation of heat is hampered. Thus, the location and morphology of the defects will become apparent in the thermal record [17]. In the present study the heating is effectuated using a halogen lamp of $500 \mathrm{~W}$. The glass lid of the lamp is removed in order to increase the intensity of infrared radiation illuminating the defected surface. Although increasing the intensity is not beneficial in thermography studies aiming to reveal subsurface defects, it does improve the detection limit for surface defects by increasing the contrast between defected and uniform areas [18]. It is further chosen to move the halogen lamp manually during recording to vary the angle of incidence of the infrared radiation. The varying angle of incidence also enhances the contrast between defected and uniform areas as the radiation is reflected in different directions, depending on the topography of the surface. The detection is done with a FLIR SC7000 camera at a recording rate of ten frames per second for a maximum time of $100 \mathrm{~s}$.

\section{Image processing of thermography data}

Due to the circumstances of acquisition for the thermography data, we could not record the configuration of the heat source over time, e.g., incident angles, location, and orientation. This obstructed direct modelling of the geometry of the underlying surface. Nonetheless, the variation of intensity observed in the thermography data provides some clues to the depth of the scratches in the surface. When processed, albeit suboptimally due to missing information, these depth clues improve readability and are thus worth investigating.

Image processing was used to distil a readable, single image of the surface from the video of thermography data. The data exhibits two informative properties: (1) defected and uniform areas respond differently to the varying angle, providing information about the topography of the surface; and (2) direct correspondences between pixels in each frame, since the sensor remained stationary. At the same time, each timestep exposes only a subset of the entire surface with sufficient visibility and the images are noisy.
An averaging operation in combination with gradientbased image editing was used to capitalise on and compensate for these properties. The underlying assumption is that the intensity values at defected areas are more stable than those at uniform areas, which are exposed by the average. Moreover, the averaging operation increases the signal-to-noise ratio $[19,20]$. The full process is as follows: a number of frames ( 2 to 4 ) were manually selected based on their readability. Next, a rectangular region of interest was annotated on each frame. For each selected frame, the $k$ most similar frames were sampled, based on Euclidean distance in image space and the gradients of the $k$ similar frames were averaged. Only the $k$ most similar images are averaged to avoid oversmoothing and to reduce the influence from outliers. Finally, the average gradients in the region of interest for each selected frame were merged into one image using Poisson integration [21].

\section{Lab-scale physical reconstruction of inscriptions according to sample stratigraphy}

In order to test the selected Non-Destructive Testing techniques, described earlier in this section, before applying them to the plastered wall section in cell 601, a lab-scale physical model wall with inscriptions was made. For the design of this wall, several core samples from neighbouring cells in the Scheveningen prison were extracted in order to determine the stratigraphy of the cell walls and the composition of their materials. It was not possible to extract a core sample from cell 601 because of its monumental status; it is therefore assumed that the wall material of cell 601 is similar to that in its neighbouring cells.

After extraction, samples of the wall cores were impregnated in epoxy, cut vertically and polished. Figure $2 \mathrm{a}$ displays a picture taken with optical microscopy of the epoxy impregnated and polished core sample extracted from cell 600, the cell north of cell 601. In the eight layers visible in Fig. 2a, the layer of yellow paint (layer 2) is identified as the surface layer during the war. Later, paint layers 3 to 6 have been applied. The layer indicated as 5 was actually void before being infused with epoxy during sample preparation. Layers 7 and 8 are plaster layers. Figure $2 \mathrm{~b}$ schematically shows the expected stratigraphy of the plastered section of the northern wall of cell 601: two layers that are identical or similar to the layers 1 and 2 of cell 600 plus the additional post-war plaster layer.

The phase constituents and chemical composition of the mortar of layer 1 of cell 600 were determined using $\mathrm{X}$-ray diffraction and X-ray fluorescence. The mixing ratios for the mortar with which the physical model wall is made are based on these results, although slight differences were inevitable. The dimensions of the 


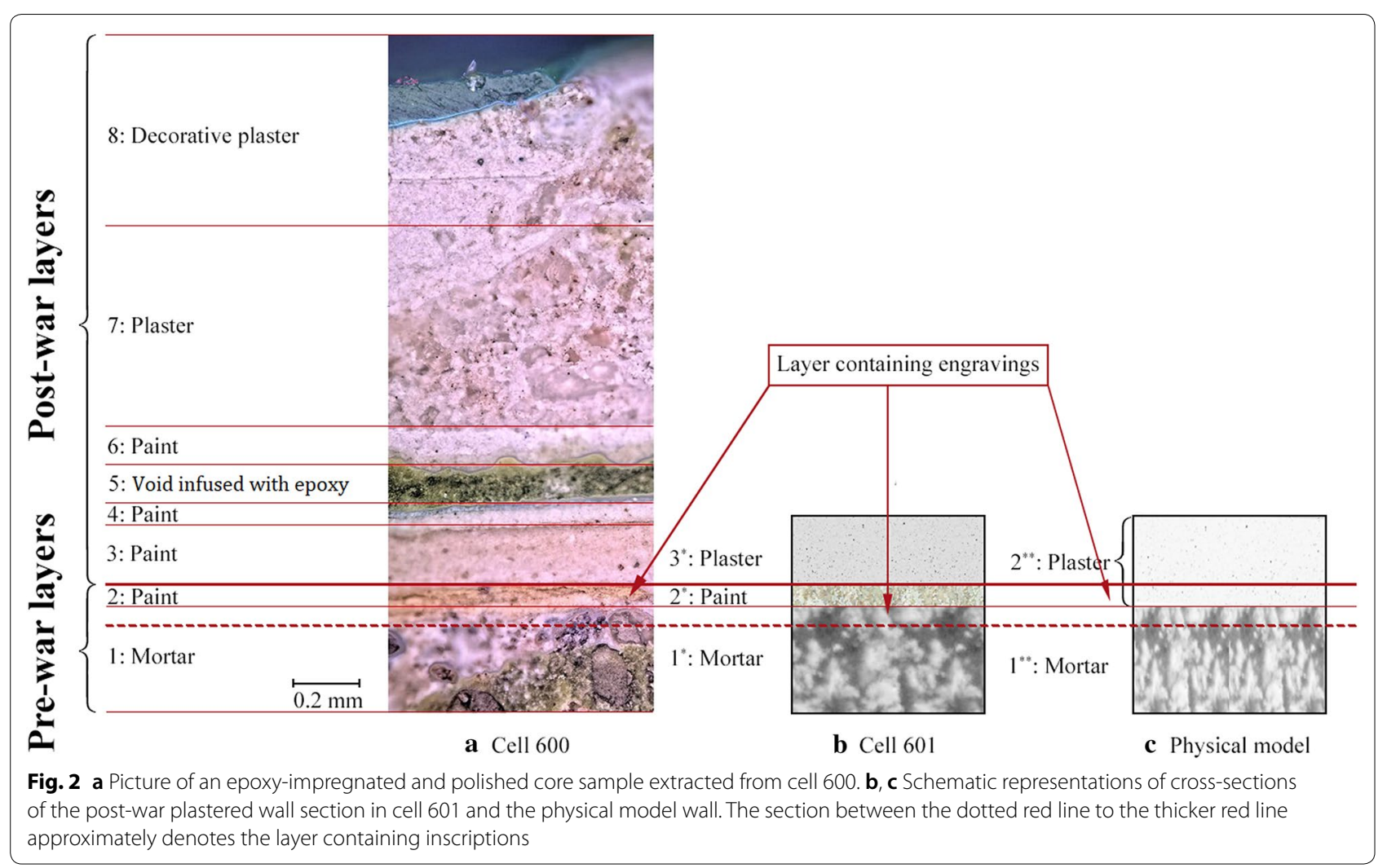

physical model wall are $0.6 \mathrm{~m} \times 0.7 \mathrm{~m} \times 0.02 \mathrm{~m}$ and it is divided into 8 sections. In each section 5 lines $(1$ to $3 \mathrm{~mm}$ deep), 8 pits ( 1 to $3.5 \mathrm{~mm}$ deep) and some letters and/or numbers ( 0.1 to $1 \mathrm{~mm}$ deep) are engraved. Two of these sections are shown in the Fig. 3a, b. On top of the mortar layer, a layer of plaster is applied (see Fig. 2c). The thickness of the plaster layer for the two sections shown in Fig. 3a, b varies between $0.3 \mathrm{~mm}$ and $0.6 \mathrm{~mm}$. This layer is sanded to obtain a flat surface.

The stratigraphy of the physical model wall and the expected stratigraphy of the plastered wall section in cell 601 are very similar. The main difference is the thickness of the mortar layer, which is $2 \mathrm{~cm}$ for the physical model wall and approximately $1 \mathrm{~cm}$ for the cell wall, with approximately $10 \mathrm{~cm}$ of brick behind the mortar.

It can however be assumed that the thermal penetration depth in the present application is less than $1 \mathrm{~cm}$. Hence, both walls can be considered infinitely thick. The mortar used in the physical model wall is similar in composition to the mortar in cell 600 of the Oranjehotel, but more finely grained. The composition of the post-war plaster in cell 601 could not be analysed and it was therefore not possible to mimic this plaster in the model wall.

\section{Results}

Raking light photography and thermography results of the physical model wall

This section describes the obtained results of the raking light photography and infrared thermography applied to the physical model wall. A selection of the obtained results is displayed in Fig. 3.

In this figure it is shown that some of the inscriptions are more clearly visible using the raking light method and others are more clearly visible by the application of thermography. One example of each of these cases is given in the figure by the red and green dotted rectangles. The red dotted rectangle contains an inscription of the letter A, see Fig. 3b. This letter can be seen clearly in the raking light photograph of the physical model wall, Fig. 3c, and less so in the thermograph, Fig. 3d. The green dotted rectangle contains five engraved vertical lines, see Fig. 3a. These lines can be seen more clearly in the thermograph than in the raking light photograph.

The visibility of defects in the raking light and thermography methods depends on the extent in which the plaster is drawn into the inscriptions and the angle of incidence of the radiation. The contrast created in the thermograph is however also dependent on the differences in the rate at which the surface is heating up. This 


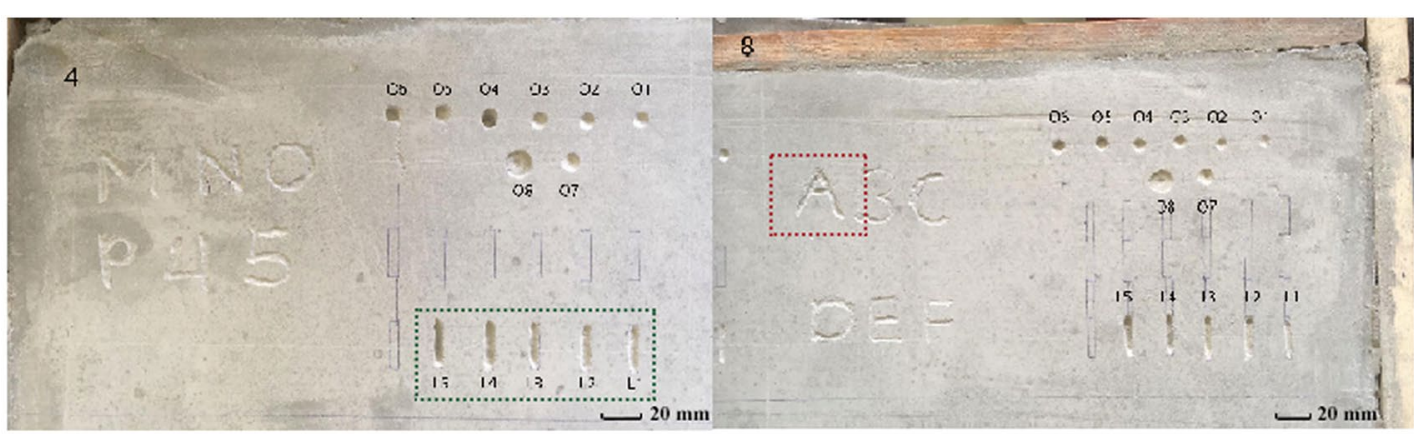

a

b

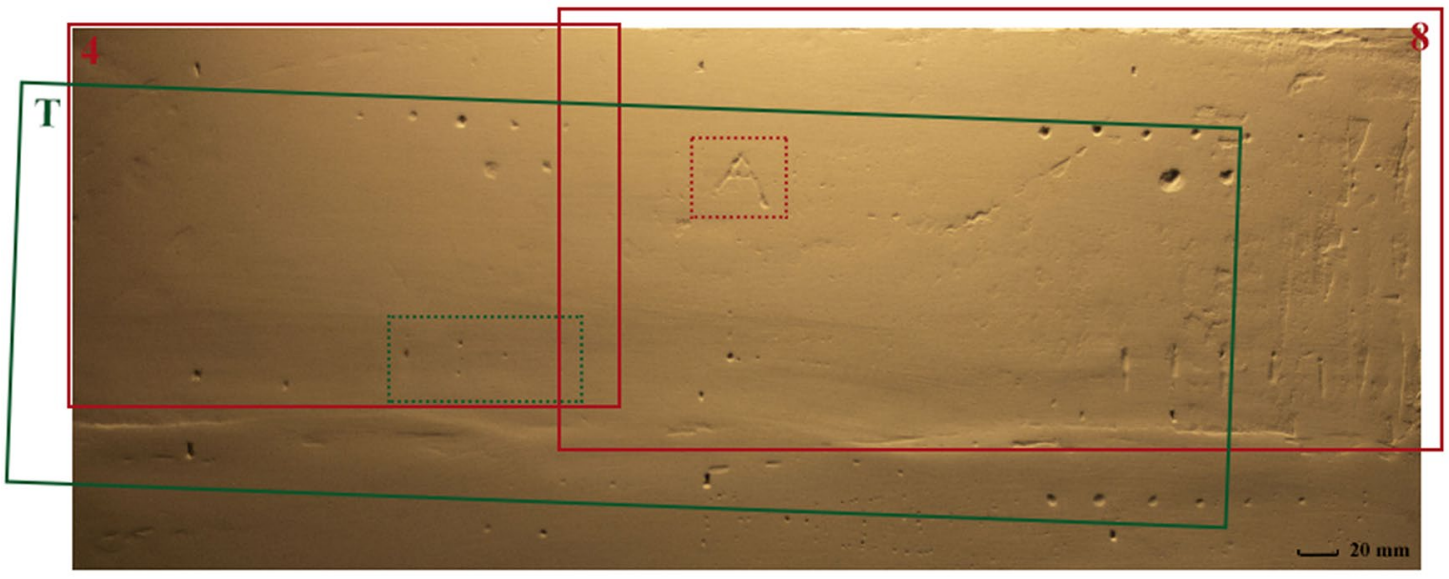

c

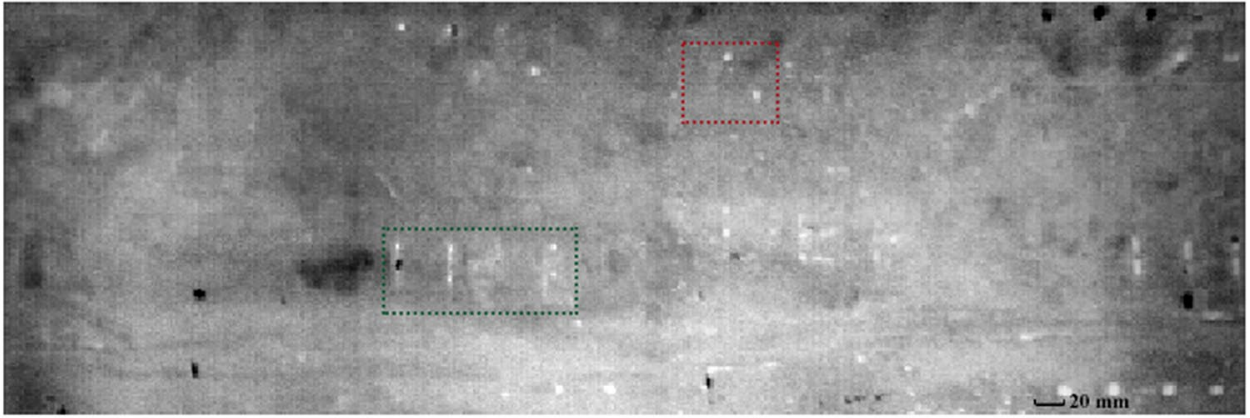

d

Fig. 3 a, b Sections 4 and 8 of the physical model wall before plastering. $\mathbf{c}$ Raking-light photograph of the physical model in which the red rectangles labelled 4 and 8 represent the two sections shown in $\mathbf{a}$ and $\mathbf{b}$. The green rectangle labeled T corresponds to the thermograph displayed in $\mathbf{d}$. The dotted rectangles mark inscriptions. The inscriptions in the red rectangle are more clearly visualized in raking-light photography, the inscriptions in the green rectangle are more clearly visualized in thermography

rate is related to the stratigraphy of the substrate, or in other words, the thickness of the plaster and the depth of the inscription.

Since the visibility of defects in thermography also depends on the stratigraphy of the material, the results that can be obtained with this method have the potential to be better than the results that can be obtained by raking light photography. However, since the visibility of the results is dependent on several factors and the stratigraphy and topography of the physical model wall are not uniform, the two methods strengthen each other, creating contrast depending on different features of the wall.

\section{Doodencel 601}

Visual inspection of cell 601 shows that the walls in the Oranjehotel were built using bricks (Fig. 1a). The cell 
walls can be divided into two parts: the eastern part and the western part, the lower resp. upper part of Fig. 1b. In the eastern part of the cell the bricks have been painted yellow and in the western part the bricks have been covered with a white painted layer of mortar. The post-war plastered section containing inscriptions is located near the bed in the western part of the northern cell wall, marked by an ellipse in Fig. 1a and an X in Fig. 1b. It is shown in Fig. 1c. Visual inspection of this section makes clear that the plaster has dried into the inscriptions, leaving traces of the inscriptions visible in the plaster's surface topography. The traces are however not sufficiently deep and consistent to identify words or other meaning on visual inspection.

Figure 4 displays results obtained by raking light photography and infrared thermography on the post-war plastered wall section in cell 601 . The raking light photograph consists of 24 pictures that were merged into a single picture using Adobe Photoshop CC 2019๑. The same software was used to optimise the visibility of the inscriptions. On some parts inscriptions seem to be present but cannot be made visible using the raking light method, due to the roughness of the surface and insufficient depth of the traces.

Three regions of the post-war plastered wall section will be discussed. Region 1 (the upper red rectangle in Fig. 4a) contains words. The raking light and thermography observations on the right-hand part of this region (the dotted rectangle in Fig. 4a) are shown in detail in Fig. 4b. The word "Scheltinga" can be read in this part. The whole region 1 contains the name De Blocq van Scheltinga. It is historically known that NSB member Daniël de Blocq van Scheltinga (1903-1962) was imprisoned in the Scheveningen prison right after the war [22].

The raking light and thermography observations on a part of region 2 (the middle red rectangle in Fig. 4a) are shown in detail in Fig. 4c. Region 2 contains an engraved calendar. Analysis of the day numbers and days of the week indicates that the calendar covers the period May 10-November 16, 1945.

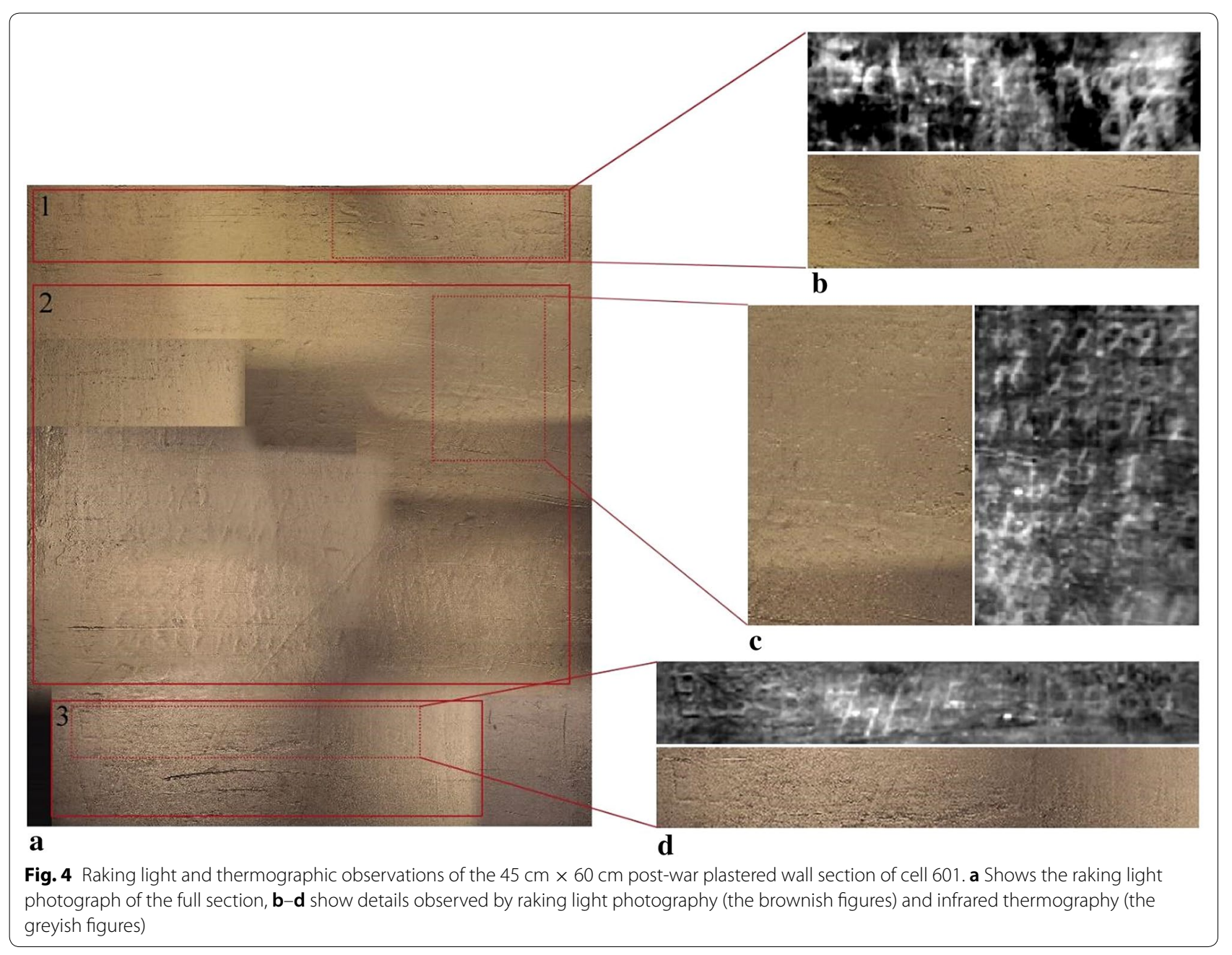


Region 3 is indicated by the lower red rectangle in Fig. 4a and the dotted rectangle is shown in detail in Fig. 4d. In this part the word "Eisch" (Dutch for prosecutor's claim) can be read, followed by an apparent date "../7/'45" and the word "Dood" (Dutch for death). However, a raking light photograph made in the preliminary study described in the Methods section shows the date to be "11/9/'45", see Fig. 5 [16]. The characteristics of the " 9 " in this date agree with the " 9 " of the 29th of July in the calendar (see Fig. 4c). There is also a text inscription below the word Eisch, but of this inscription only the two letters "Vo" can be read. Possibly the full word is "Vonnis" (Dutch for verdict). The rest of the line cannot be read.

A complete transcript of the texts that the authors, to the best of their ability, have distinguished in the analysed wall section is given in Fig. 6 . Note that the vertical letter sequence $\mathrm{Z}-\mathrm{M}-\mathrm{D}-\mathrm{W}-\mathrm{D}-\mathrm{V}-\mathrm{Z}$ indicates the weekdays in Dutch, starting with Sunday.

\section{Discussion}

The combination of raking light photography and infrared thermography using a variable illumination angle has shown to be effective in revealing inscriptions in a historically interesting section of the walls of Doodencel 601 of the Oranjehotel. Whereas neither of the two techniques delivers full revelation of the inscriptions, the combination greatly enhances the legibility of the inscriptions.

There is great historical interest in revealing wartime and post-war inscriptions that are present in the other cells of the Oranjehotel [2]. The raking light technique has the limitation that it is only effective if traces of inscriptions are present in the surface of the investigated wall. This is not the case for the walls of all other cells of the Oranjehotel. Therefore, for future investigations on other cell walls, only thermography could be applied.

The analysis of the epoxy-impregnated core sample from cell 600 (Fig. 2a) has shown that the walls of the other cells have been plastered and painted several times since the war, consistent with [3]. The sample further contains a layer that absorbed epoxy during sample preparation (layer 5). Therefore, it can be expected to originally contain air bubbles. If present, this layer, in combination with the new layers of plaster and paint covering the inscriptions, will be a strongly disturbing factor when analysing wartime inscriptions (layer 2 in Fig. 2a) using infrared thermography. Such studies, as well as more detailed studies of cell 601, can be optimised by using a more accurate procedure for heating and recording within the limitations posed by the monumental status of cell 601.

The historically interesting section of the walls of Doodencel 601 that has been investigated in the present study contains inscriptions of which the author can be readily identified as Daniël de Blocq van Scheltinga (1903-1962), a prominent member of the Dutch National Socialist party NSB (Fig. 7a) [22]. Coming from an aristocratic family, squire De Blocq van Scheltinga married the daughter of an aide-de-camp of the German emperor Wilhelm II, who lived in Dutch exile after World War I. With his fervent pro-German attitude De Blocq van Scheltinga joined the NSB in 1932. He quickly moved up and soon headed the NSB party office, working closely with the infamous NSB leader Anton Mussert. In 1942 De Blocq van Scheltinga was appointed mayor of Wassenaar, an affluent community near The Hague and home to important Dutch and German Nazi officials. At his personal initiative he asked the German police (Grüne Polizei) in September 1942 to 'evacuate' the local Jewish community. He was active in the deportation of several political and personal opponents to forced-labour camps in Germany [22]. The Nazi occupation of the Netherlands ended on May 5, 1945. On May 7 Daniël De Blocq van Scheltinga was arrested and imprisoned in Scheveningen during his trial before the Bijzonder Gerechtshof, the Special Court of Justice, which judged Dutch collaborators and war criminals. His post-war imprisonment and trial are documented in the archives of the Dutch Bijzonder Gerechtshof [23].

De Blocq van Scheltinga's legal proceedings were part of the first wave of post-war trials held in the Netherlands, which included the most important Dutch National Socialist leaders Anton Mussert, Max Blokzijl and Robert van Genechten. In Fig. 7b, De Blocq van Scheltinga is shown in the company of these men on an undated photograph, taken inside the walls of the Scheveningen prison, most likely in the fall of 1945. The

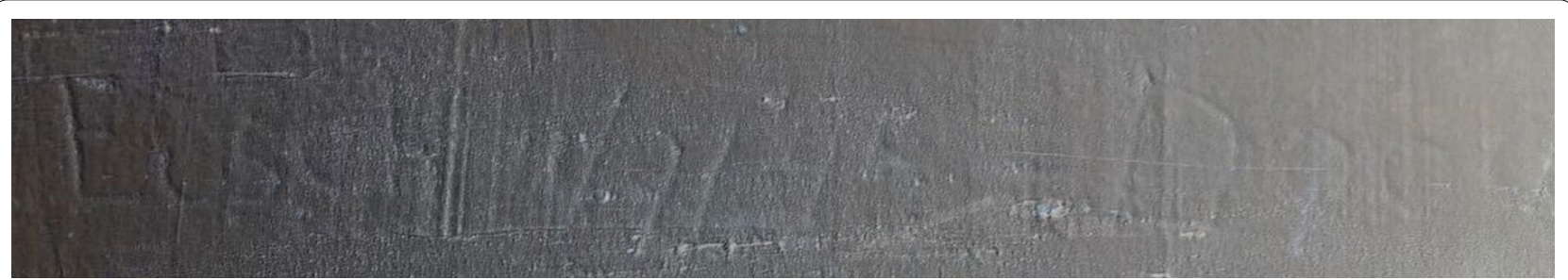

Fig. 5 Raking light photograph made in a preliminary study of the detail shown in Fig. 4d). [16] 


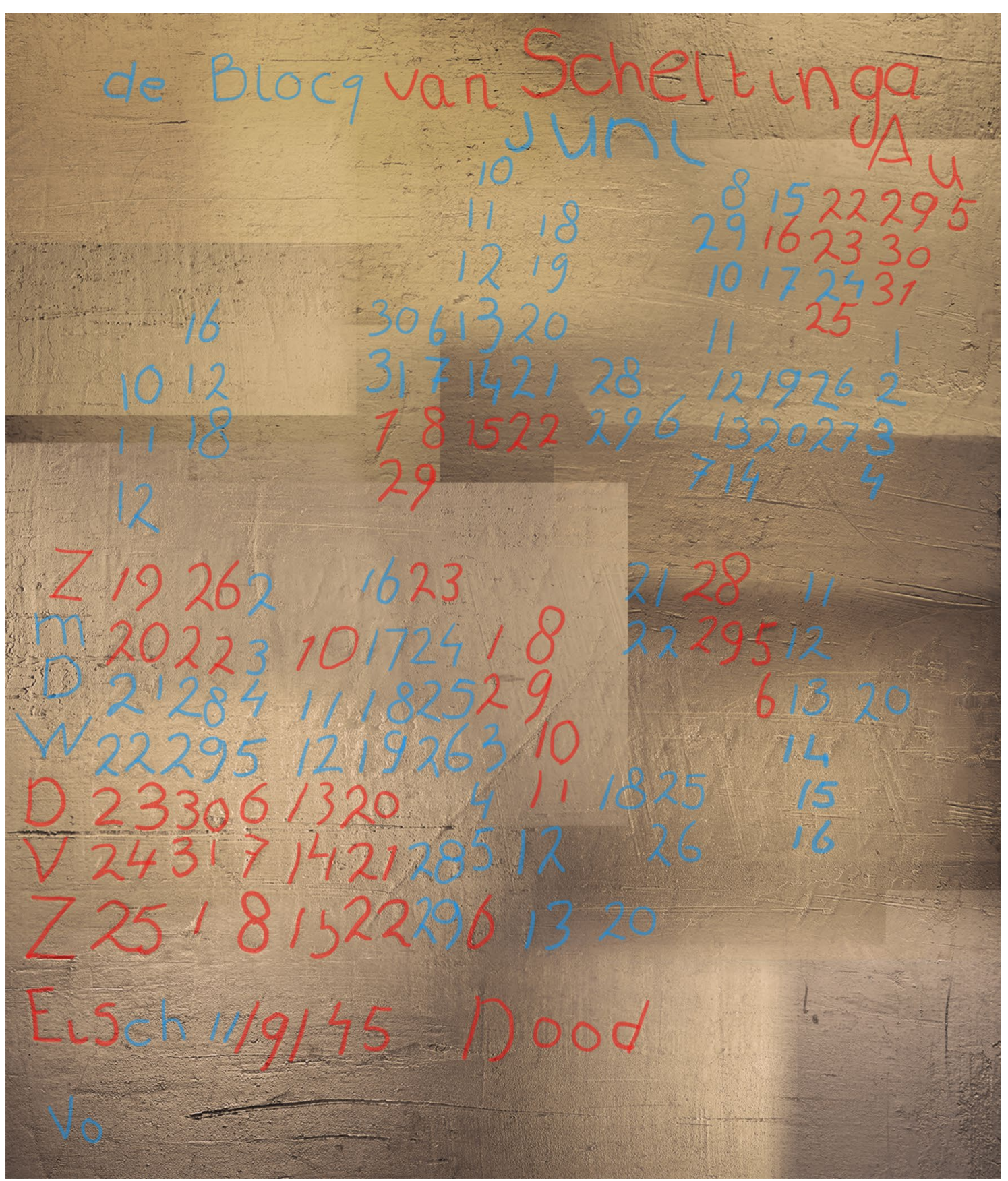

Fig. 6 Composition of photographs made of the post-war plastered wall section in Doodencel 601. Inscriptions that are revealed by both raking light photography and infrared thermography are shown in red; inscriptions that are detected by infrared thermography only are shown in blue

three other men were sentenced to death; Mussert and Blokzijl were executed, Van Genechten committed suicide in the prison.

De Blocq van Scheltinga has chosen to leave a clear sign of his detention in the Scheveningen prison by a relatively large inscription stating his name. The checkerboard calendar below De Blocq van Scheltinga's name contains the dates of several months, most distinctly recognised by a sequence of Fridays in subsequent months on the days 11-1-6-3-7-5-16. This sequence is consistent, as the only possibility in the 1940s, with the Fridays May 11, June 1, July 6, August 3, September 7, October 


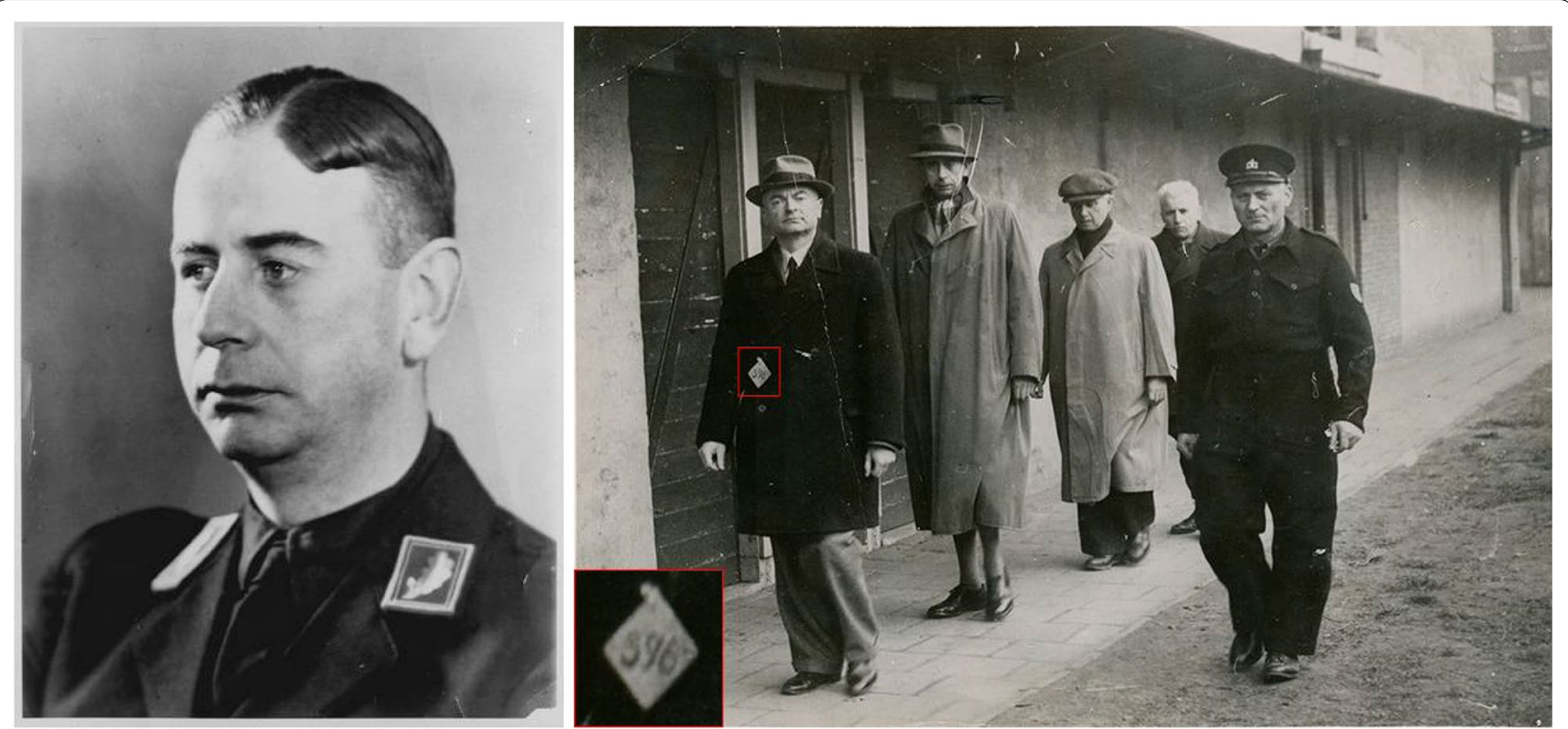

Fig. 7 a Daniël de Blocq van Scheltinga in NSB uniform during the war (source: Beeldbank WO2-NIOD-picture nr. 24645. b The NSB leaders Mussert, De Blocq van Scheltinga, Blokzijl, Van Genechten in the Scheveningen prison after the war (source: Beeldbank WO2-NIOD-picture nr. 48174). The picture's location is indicated by Mussert's overcoat, showing nr 596 (enlarged in the lower left corner in red), the number of his cell in Scheveningen [24]

5, November 16, 1945. This period is in agreement with the period of De Blocq van Scheltinga's detention for hearings and trial. The texts below the calendar, "Eisch", "11/9/'45", "Dood", match the archival records, in which it is documented that the prosecutor sought (Eisch) the death penalty (Dood) on September 11, 1945 [22]. Two weeks later the court sentenced De Blocq van Scheltinga to lifelong imprisonment. On December 5, 1945 the Special Court of Appeals commuted the sentence to 20 years of imprisonment. Following that final sentence, De Blocq van Scheltinga was transferred to the Leeuwarden prison in the north of the Netherlands. This means that, consistent with the revealed calendar, in November 1945 he was still in the Scheveningen prison. Eight years later, at his family's initiative, he was pardoned by the Dutch crown and released from prison in 1953. De Blocq van Scheltinga moved to Düsseldorf in Germany in 1958, where he passed away in 1962 [22].

The inscriptions that De Blocq van Scheltinga engraved in the wall of his cell 601 of the Scheveningen prison do not significantly differ from inscriptions by wartime prisoners of the Oranjehotel. Being suspected of committing crimes according to the ruling legal system, the prisoner on trial testifies of his anxiety during slowly passing days, awaiting the verdict. De Blocq van Scheltinga's inscriptions are the first inscriptions to be found of Nazi collaborators during the Bijzondere Rechtspleging, the procedures of the post-war Dutch Special Court of Justice. All other inscriptions in cell 601 as well as the numerous inscriptions of the Oranjehotel as recorded in E.P. Weber's Gedenkboek van het Oranjehotel [2], testify of the anxiety of Dutchmen subjected to the depraved Nazi judicial system, enabling and justifying brutalities during the occupation.

\section{Conclusions}

Raking light photography and infrared thermography were applied in a combined approach for non-destructive investigations of a specific section of the walls of Doodencel 601 of the Dutch wartime prison Oranjehotel. The combination of these methods enabled the analysis of the inscriptions below a post-war plaster layer. The inscriptions consist of a name, a calendar and several separate words. The name is De Blocq van Scheltinga, the calendar is of the period May-November 1945 and the words are indicating the prosecutor's claim for the death penalty in September 1945 . The verdict is possibly engraved as well, but cannot be read. These observations show that NSB leader Daniël de Blocq van Scheltinga was imprisoned in cell 601 of the Scheveningen prison during his trial for the Bijzonder Gerechtshof, before being transported to Leeuwarden for long-term imprisonment. These inscriptions are the first revealed inscriptions made by Nazi collaborators on post-war trial. 


\section{Abbreviations}

NDT: Non-destructive testing; NSB: Nationaal-Socialistische Beweging, NationalSocialist Movement; RTI: Reflectance transformation imaging.

\section{Acknowledgements}

We would like to acknowledge the Nationaal Monument Oranjehotel for their enthusiastic support of this project, and particularly its director Anke van der Laan. Tim Zaman kindly provided an unpublished image from his earlier inspection of Doodencel 601. The Delft University Fund provided financial support for the contribution of Ruben Wiersma.

\section{Funding}

The Delft University Fund provided financial support for the contribution of Wiersma.

\section{Competing interests}

This research was conducted as part of an academic B.Sc. thesis of Wempe, Van den Brink, Mooldijk and Feirabend, supported by the imaging work of Wiersma, and supervised by Sietsma and Dik. The manuscript was written in close collaboration and approved by all authors. The datasets used and/or analysed during the current study are available from the authors on reasonable request. Sietsma is an unpaid board member of the Stichting Oranjehotel, a foundation associated with the Nationaal Monument Oranjehotel. Other competing interests are not applicable.

\section{Author details}

${ }^{1}$ Dept. Materials Science and Engineering, Delft University of Technology, Mekelweg 2, 2628 CD Delft, The Netherlands. ${ }^{2}$ Dept. Computer Graphics and Visualization, Delft University of Technology, Van Mourik Broekmanweg 6, 2628 XE Delft, The Netherlands.

Received: 17 April 2020 Accepted: 16 July 2020

Published online: 24 July 2020

\section{References}

1. von Benda-Beckmann B, Het Oranjehotel: Een Duitse gevangenis in Scheveningen, Amsterdam, 2019

2. Weber EP, Gedenkboek van het Oranje Hotel, Amsterdam, 1947

3. Heijenbrok JH, Steenmeijer GHP, Dodencel 601 in het Penitentiair Complex Scheveningen, Bouwhistorische Aantekening, The Hague, 2001

4. Terwiel JM, Bajes in de duinen 1880-2000, The Hague, 2000

5. Grinzato E, Berssan C, Marinetti S, Bison PG, Botanica C, Monitoring of the Scrovegni Chapel by IR thermography: Giotto at infrared, Infrared Phys Technol, 2002, 43, 165-9

6. Avdelidis NP, Moropoulou A, Applications of infrared thermography for the investigation of historic structures, J Cult Herit, 2004, 5, 119-27

7. Ambrosini D, Daffara C, Di Biase R, Paoletti D, Pezzati L, Bellucci R, Bettini $F$, Integrated reflectography and thermography for wooden paintings diagnostics, J Cult Herit, 2010, 11, 196-204

8. Davin T, Serio B, Guida G, Pina V, Spatial resolution optimization of a cooling-down thermal imaging method to reveal hidden academic frescoes, Int J Therm Sci, 2017, 112, 188-98

9. Daffara C, Parisotto S, Mariotti, Pl, Mid-infrared thermal imaging for an effective mapping of surface materials and sub-surface detachments in mural paintings: integration of thermography and thermal quasi-reflectography, Proceedings of SPIE-The International Society for Optical Engineering, 2015, Munich, Germany

10. Sfarra S, Ibarra-Castanedo C, Ambrosini D, Paoletti D, Bendada A, Maldague $X$, The use of optical and infrared techniques for the restoration of the frescoes damaged by earthquake: A case study - The fresco of Giacomo Farelli in the Church of Santa Maria della Croce di Roio (L'Aquila, Italy), Structural Studies, Repairs and Maintenance of Heritage Architecture XII, 2011, 118, 627-641

11. Adam A, Planken P, Meloni S, Dik J, TeraHertz imaging of hidden paint layers on canvas, Opt Express, 2009, 17, 3407-3416

12. Liang H, Gomez Cid M, Cucu RG, Dobre GM, Podoleanu AG, Pedro J, Saunders D, En-face optical coherence tomography-a novel application of non-invasive imaging to art conservation, Opt Express, 2005, 13, 6133-6144

13. Jackson JB, Mourou M, Whitaker JF, Duling IN, Williamson SL, Menu M, Mourou GA, Terahertz imaging for non-destructive evaluation of mural paintings, Opt Commun, 2008, 281, 527-532

14. Malzbender T, Gelb H, Wolters H, Polynomial texture maps, SIGGRAPH'01 Proceedings of the 28th annual conference on computer graphics and interactive techniques, 2001, 519-28

15. DiBiasie Sammons JF, Application of Reflectance Transformation Imaging (RTI) to the study of ancient graffiti from Herculaneum, Italy, J Archaeol Sci Rep, 2018, 17, 184-94

16. Zaman T, Personal communication, Delft University of Technology, 2016

17. McCann DM, Forde MC, Review of NDT methods in the assessment of concrete and masonry structures, NDT \& E Int, 2001, 34, 71-84

18. Runnemalm A, Broberg P, Surface crack detection using infrared thermography and ultraviolet excitation, 12th international conference on quantitative infrared thermography, 2014

19. Van Drongelen W, Signal averaging, in: Van Drongelen W (edit.), Signal processing for neuroscientists: introduction to the analysis of physiological signals, Elsevier, 2007, 55-70

20. Holmes C, Hoge R, Collings L, Woods R, Toga A, Evans A, Enhancement of MR images using registration for signal averaging, J Comput Assist Tomogr, 1998, 22, 324-33

21. Pérez $P$, Gangnet $M$, Blake A, Poisson image editing, ACM Trans Graph, 2003, 22, 313-318

22. Zondergeld GR. Blocq van Scheltinga, jhr. Daniël de (1903-1962), Biografisch Woordenboek van Nederland (BNW) 1880-2000, http://resou rces.huygens.knaw.nl/bwn1880-2000/lemmata/bwn5/blocq,accessed 6 Apr 2020

23. We consulted the postwar judicial dossier on De Bloca van Scheltinga on August 20th, 2019 in the National Archives in the Hague: Centraal Archief Bijzondere Rechtspleging (CABR), CABR (2.09.09), CABR 102837 (PRA Den Haag dossier 5760/IX/45), CABR 78899 (Gratie Adviescommissie dossier D. de Blocq van Scheltinga), CABR 74359 (BRC), Zuivering Ambtenaren, ZA (2.04.67)

24. Mussert MJ, Een politiek leven, Amsterdam, 1984

\section{Publisher's Note}

Springer Nature remains neutral with regard to jurisdictional claims in published maps and institutional affiliations. 